\title{
The thermal decomposition of studtite: analysis of the amorphous phase
}

\author{
Nathan B. A. Thompson ${ }^{1}$ (D ) Victoria L. Frankland ${ }^{2} \cdot$ Joshua W. G. Bright ${ }^{2} \cdot$ David Read $^{2,3} \cdot$ Matthew R. Gilbert $^{4}$. \\ Martin C. Stennett ${ }^{1} \cdot$ Neil C. Hyatt $^{1}$
}

Received: 29 November 2020 / Accepted: 15 January 2021 / Published online: 15 February 2021

(c) The Author(s) 2021

\begin{abstract}
Studtite is known to exist at the back-end of the nuclear fuel cycle as an intermediate phase formed in the reprocessing of spent nuclear fuel. In the thermal decomposition of studtite, an amorphous phase is obtained at calcination temperatures between 200 and $500{ }^{\circ} \mathrm{C}$. This amorphous compound, referred to elsewhere in the literature as $\mathrm{U}_{2} \mathrm{O}_{7}$, has been characterised by analytical spectroscopic methods. The local structure of the amorphous compound has been found to contain uranyl bonding by X-ray absorption near edge (XANES), Fourier transform infrared and Raman spectroscopy. Changes in bond distances in the uranyl group are discussed with respect to studtite calcination temperature. The reaction of the amorphous compound with water to form metaschoepite is also discussed and compared with the structure of schoepite and metaschoepite by X-ray diffraction. A novel schematic reaction mechanism for the thermal decomposition of studtite is proposed.
\end{abstract}

Keywords Studtite $\cdot$ Thermal decomposition $\cdot$ Spectroscopy $\cdot$ Uranium oxide

\section{Introduction}

In the reprocessing of spent nuclear fuel (SNF), uranium can be dissolved as uranyl nitrate hexahydrate

Nathan B. A. Thompson

NBAThompson2@gmail.co.uk;

NBAThompson1@Sheffield.ac.uk

Victoria L. Frankland

V.Frankland@Surrey.ac.uk

Joshua W. G. Bright

J.Bright@Surrey.ac.uk

David Read

D.Read@Surrey.ac.uk

Matthew R. Gilbert

Matthew.Gilbert@AWE.co.uk

Martin C. Stennett

M.C.Stennett@Sheffield.ac.uk

Neil C. Hyatt

N.C.Hyatt@Sheffield.ac.uk

1 Department of Materials Science and Engineering, University of Sheffield, Sheffield S10 2TN, UK

2 School of Chemistry and Chemical Engineering, University of Surrey, Guildford GU2 7XH, UK

3 National Physical Laboratory, Teddington TW11 0LW, UK

4 AWE, Aldermaston, Reading RG7 4PR, UK $\left(\mathrm{UO}_{2}\left(\mathrm{NO}_{3}\right)_{2} \cdot 6 \mathrm{H}_{2} \mathrm{O}, \mathrm{UNH}\right)$, and precipitated with hydrogen peroxide $\left(\mathrm{H}_{2} \mathrm{O}_{2}\right)$ to form uranyl peroxide tetrahydrate, also known by the mineral name, studtite $\left(\left[\left(\mathrm{UO}_{2}\right)\left(\mathrm{O}_{2}\right)\right.\right.$ $\left.\left.\left(\mathrm{H}_{2} \mathrm{O}\right)_{2}\right] \cdot 2 \mathrm{H}_{2} \mathrm{O}\right)$ (Fig. 1). It has previously been shown that studtite dehydrates into uranyl peroxide dihydrate (metastudtite; $\left.\left[\left(\mathrm{UO}_{2}\right)\left(\mathrm{O}_{2}\right)\left(\mathrm{H}_{2} \mathrm{O}\right)_{2}\right] \cdot 2 \mathrm{H}_{2} \mathrm{O}\right)$ when heated to $100{ }^{\circ} \mathrm{C}$ [1-4]. By $200{ }^{\circ} \mathrm{C}$, metastudtite decomposes into an amorphous phase before it is calcined further to $\alpha-\mathrm{UO}_{3}$ (Fig. 1, right) and $\alpha-\mathrm{U}_{3} \mathrm{O}_{8}$ at temperatures above $500{ }^{\circ} \mathrm{C}[1-5]$.

$\mathrm{X}$-ray diffraction (XRD) analysis has previously revealed that studtite consists of chains of edge-sharing hexagonal bipyramids containing two peroxide groups (O-O; Fig. 1, left) [6]. Both O atoms in the two peroxide groups are bonded to the central uranium atom with the remaining two vertices in the bipyramid occupied by water molecules. A further two water molecules are located between the chains; it is the loss of these water molecules that results in the formation of metastudtite. [1-4] In addition to its occurrence in spent fuel reprocessing, both studtite and metastudtite are formed in natural uranium deposits and during nuclear waste storage 


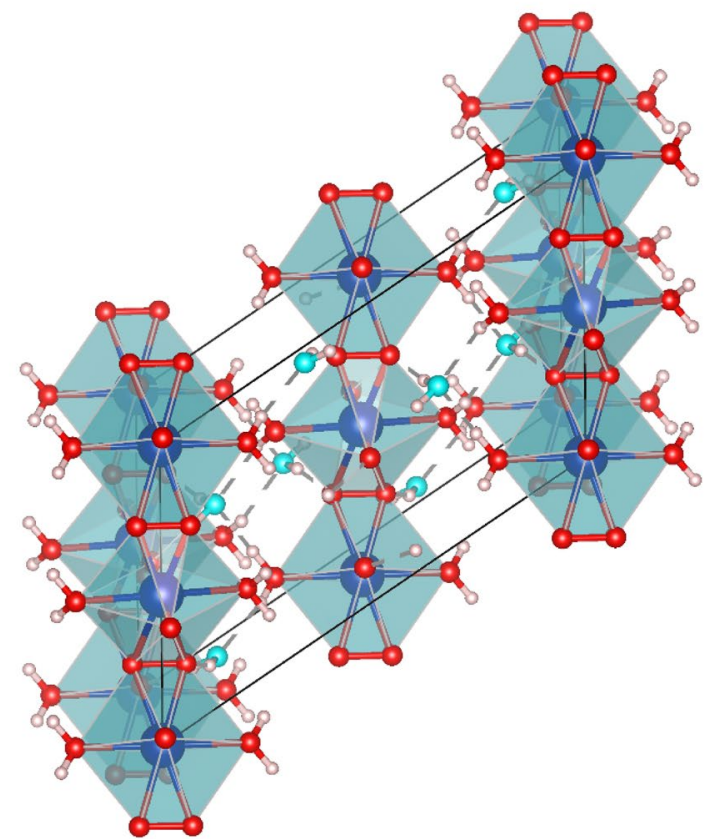

Studtite

Fig. 1 Schematic image of the crystal structures for studtite, $\left(\left[\left(\mathrm{UO}_{2}\right)\right.\right.$ $\left.\left.\left(\mathrm{O}_{2}\right)\left(\mathrm{H}_{2} \mathrm{O}\right)_{2}\right] \cdot 2 \mathrm{H}_{2} \mathrm{O}\right)$, left $)$ and $\alpha$-uranium trioxide $\left(\alpha-\mathrm{UO}_{3}\right.$, right $)$. Both are viewed along the $b$-axis, perpendicular to the c-axis. The elements

through the build-up of hydrogen peroxide produced by $\alpha$-radiolysis of water [7]. XRD analysis of $\alpha-\mathrm{UO}_{3}$ reveals that this species is formed of hexagonal sheets bonded together by axial O-atoms (Fig. 1, right) [8,9].

The thermal decomposition of studtite has been characterised by the use of spectroscopic techniques including XRD, Fourier transform infrared (FTIR) and Raman spectroscopy [1,2]; however, the amorphous phase has only briefly been alluded to in the literature [2]. In addition to methods employed previously, this study makes use of X-ray absorption near edge spectroscopy (XANES), Raman and fluorescence spectroscopy, to build on current understanding of the local structure and bonding in the amorphous compound. Some recent studies have addressed the characterisation of this material, reporting it either to be stoichiometric $\mathrm{U}_{2} \mathrm{O}_{7}$ or an amorphous $\mathrm{UO}_{3}$ hydrate. Both computational and experimental efforts have aided in elucidating the short-range structure, although there has been little agreement on either its structure or stoichiometry [2, 10, 11]. It has been demonstrated by density functional theory (DFT) and neutron scattering analysis that the compound may contain uranyl cation units $\left(\mathrm{UO}_{2}{ }^{2+}\right)$ and peroxide groups $(\mathrm{O}-\mathrm{O})$, although further exploration of the amorphous structure is required. As the material is X-ray amorphous, the long-range structure of this material is difficult to determine, and is highly likely to be disordered.

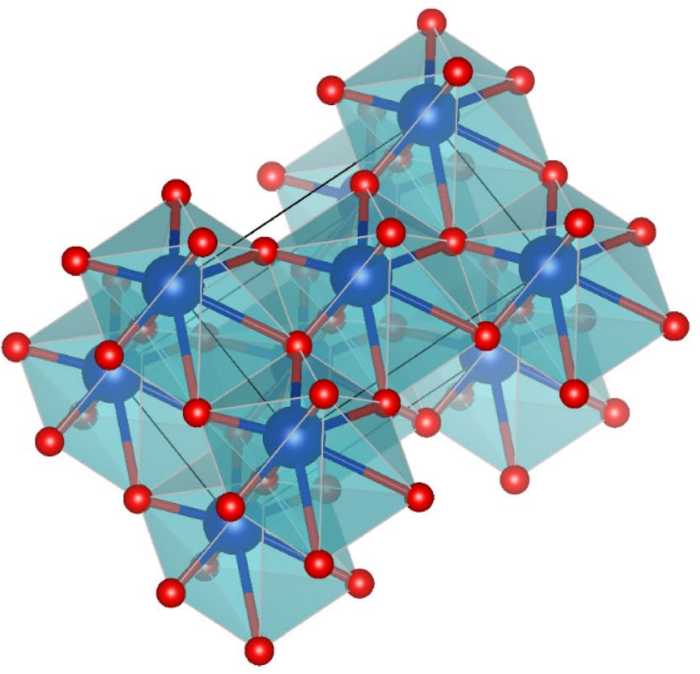

$\alpha-\mathrm{UO}_{3}$

$\mathrm{U}, \mathrm{O}$ and $\mathrm{H}$ are shown in blue, red and white, respectively. [8, 9] Water $\mathrm{O}$ atoms are light blue

The mechanism by which studtite decomposes to form the amorphous phase has not yet been reported. Given its existence as an intermediate in the thermal decomposition of studtite, it is important that the compound is well characterised in order to understand the mechanism for transformation of studtite to $\alpha-\mathrm{UO}_{3}$. This paper aims to characterise the amorphous phase spectroscopically, within the wider context of the thermal decomposition of studtite and its products of thermal decomposition.

\section{Experimental methods}

\section{Sample preparation}

Studtite was precipitated by reaction of uranyl nitrate hexahydrate (BDH Chemicals, $0.5 \mathrm{M}$ ) with hydrogen peroxide (Sigma Aldrich ${ }^{\circledR}$ reagent grade, $30 \mathrm{w} / \mathrm{w} \%$ ). The precipitate was filtered under reduced pressure and allowed to dry in air for $48 \mathrm{~h}$, before being heated to 100 , $150,250,350,450,500,550,650$ and $1050{ }^{\circ} \mathrm{C}$ in a nitrogen atmosphere at a rate of $10{ }^{\circ} \mathrm{C} \mathrm{min}{ }^{-1}$. A Netszch TG $449 \mathrm{~F} 3$ Jupiter simultaneous thermal analyser was used for accuracy of heating temperature $\left( \pm 0.01{ }^{\circ} \mathrm{C}\right)$. Studtite and metastudtite were pale yellow in colour, previously assigned by objective colour analysis as Pantone ${ }^{\mathrm{TM}} \mathrm{P} 8-9$ 
C and P 19-9 C, respectively [12]. The amorphous phase samples $\left(250-500{ }^{\circ} \mathrm{C}\right)$ were bright orange $\left(250{ }^{\circ} \mathrm{C}\right.$ P24-13 $\mathrm{U} ; 350{ }^{\circ} \mathrm{C}$ P $17-16 \mathrm{U}$; $450{ }^{\circ} \mathrm{C} 7572 \mathrm{XGC}$; $500{ }^{\circ} \mathrm{C}$ P $25-6$ $\mathrm{C})$, while $\alpha-\mathrm{UO}_{3}$ was brown $\left(550{ }^{\circ} \mathrm{C} 18-0521 \mathrm{TCX}\right)$. The sample phases were confirmed by XRD (Supplementary Information, Figure S1).

Those samples heated between 30 and $550{ }^{\circ} \mathrm{C}$ were characterised by FTIR, Raman and fluorescence spectroscopy at room temperature. XANES analysis was also performed on the 650 and $1050{ }^{\circ} \mathrm{C}$ samples to confirm the oxidation state of uranium. Roughly $50 \mathrm{mg}$ amorphous powder was placed in a small plastic weighing boat and mixed with $5 \mathrm{~mL}$ deionised water and allowed to dry, producing a yellow powder.

\section{X-Ray absorption near edge spectroscopy}

X-ray absorption spectroscopy was carried out on beamline BL-27B at The Photon Factory (PF), High Energy Accelerator Research Organisation (KEK), Japan [13]. The $\mathrm{PF}$ operates at $2.5 \mathrm{GeV}$ with a ring current of $300 \mathrm{~mA}$ and supplies X-rays in the energy range $4-20 \mathrm{keV}$ into beamline BL-27B, via a bending magnet. The optics hutch contains a double crystal Si (111) monochromator and a bent plane $\mathrm{SiO}_{2}$ mirror. Spectra were collected in transmission mode on finely ground powder specimens dispersed in polyethylene and pressed into pellets; the thickness of the samples was optimised to one absorption length. Slits were used to reduce the unfocussed beam size to $0.5 \mathrm{~mm}$ in the vertical and $6 \mathrm{~mm}$ in the horizontal. The X-ray intensity of the incident and transmitted beam was measured using gas-filled ionisation chambers. Spectra were recorded between 16,765 and $18,265 \mathrm{eV}$ with energy steps of $4 \mathrm{eV}(16,765$ - 17,000), $0.5 \mathrm{eV}(17,000-17,300), 1 \mathrm{eV}$ $(17,300-17,665)$, and $4 \mathrm{eV}(17,665-18,265)$. An accumulation time of $1 \mathrm{~s} \mathrm{step}^{-1}$ was used for all regions. For each sample, multiple spectra were acquired and averaged to improve the signal to noise. Absolute energy calibration of the monochromator was performed by measuring a Mo foil and aligning the edge position (measured at the first inflection point in the derivative of the absorption) to the expected value of $20,000 \mathrm{keV}$ [14]. To ensure energy reproducibility $( \pm 0.05 \mathrm{eV})$ between sets of scans, a spectrum was collected from yttrium oxide $\left(\mathrm{Y}_{2} \mathrm{O}_{3}\right)$ after each sample. The spectral data were analysed using the Demeter analysis package; data normalisation was carried out using Athena, and fitting was performed in Artemis [15]. Artemis uses the FEFF code to perform ab initio multiple scattering calculations based on clusters of atoms generated from crystallographic information files (CIF).

\section{Fourier transform infrared spectroscopy}

Fourier transform infrared spectroscopy (FTIR) was performed using a Perkin Elmer Frontier FTIR spectrometer with an attenuated total reflectance (ATR) crystal. Samples were prepared with potassium bromide $(\mathrm{KBr})$ and pelleted into discs for spectroscopy. Spectral data were collected over a range of 600 to $3800 \mathrm{~cm}^{-1}$ and processed in Origin software (Origin(Pro) version 2017, OriginLab Corporation) [16].

\section{Raman spectroscopy}

For Raman and TRLFS characterisation, each sample was placed into a groove between two quartz slides. A Renishaw InVia Reflex Raman Microscope was used to collect Raman spectra from each sample with a diode $785 \mathrm{~nm}$ laser [17]. The microscope was calibrated using silicon to ensure peak position accuracy of $\pm 1 \mathrm{~cm}^{-1}$. Spectra were collected between 4000 to $50 \mathrm{~cm}^{-1}$ from a least three different locations to confirm sample homogeneity.

\section{Fluorescence spectroscopy}

Fluorescence spectra were obtained using the timeresolved laser fluorescence spectroscopy (TRLFS) apparatus described elsewhere [18]. Fluorescence excitation and emission spectra were collected at room temperature using a xenon lamp between 280 to $490 \mathrm{~nm}$ and 450 to $650 \mathrm{~nm}$, respectively. The excitation and emission bandwidths were both set to $1.5 \mathrm{~nm}$ with a spectral resolution of $0.1 \mathrm{~nm}$ and a dwell time of $2.0 \mathrm{~s}$. The data were background corrected using the files supplied by the manufacturer (F980 version 1.4.3., Edinburgh Instruments).

\section{X-ray diffraction}

A Bruker D2 Phaser diffractometer was used to obtain $\mathrm{X}$-Ray diffraction data with $\mathrm{Ni}$ filtered $\mathrm{Cu} \mathrm{K} \alpha$ radiation and a position sensitive detector. Diffraction patterns were collected between $10<2 \theta<70^{\circ}$ at $3 \% \mathrm{~min}$, and $0.02^{\circ}$ step size. Diffraction patterns were analysed using Bruker's DIFFRAC.EVA software and processed with Origin.

\section{Results and discussion}

\section{Chemical composition and phase purity}

All samples analysed in this study were confirmed by XRD analysis (Supplementary Information, Figure S1) [19]. Samples heated to 30 and $150{ }^{\circ} \mathrm{C}$ were indexed as studtite and metastudtite, respectively $[8,20]$. Heating studtite to 
temperatures between 250 and $500{ }^{\circ} \mathrm{C}$ gave rise to two broad peaks, indicating the presence of an amorphous phase. $\alpha-\mathrm{UO}_{3}$ was formed by $550{ }^{\circ} \mathrm{C}$ [9]. Previous findings from thermogravimetric analysis (Supplementary Information, Figure S2) coupled with mass spectrometry (TGA-MS) allowed confirmation of phase transitions with respect to mass loss over a temperature range of $30-1050{ }^{\circ} \mathrm{C}$ in a $\mathrm{N}_{2}$ atmosphere [19, 21]. The evolution of gas was monitored by MS, which helped to confirm the phase transitions in combination with the findings by XRD. A full discussion of these results is published elsewhere, where the weight loss determined between metastudtite and the amorphous phase was $10.7 \%$ against an expected $11.7 \%$ [19]; this gave a formula of $\mathrm{U}_{2} \mathrm{O}_{7.3}$.

\section{XANES analysis}

The $\mathrm{U} \mathrm{L}_{3}$ XANES spectra of studtite heat treated from room temperature to $1050{ }^{\circ} \mathrm{C}$, are shown in Fig. 2. All spectra exhibited a prominent, broad absorption edge, referred to here as the 'white line' (Feature A, Fig. 2). For the studtite and metastudtite samples, these were situated at $17,177.2 \mathrm{eV}$ and 17,177.3 eV, respectively and there was also a broad shoulder peak (Feature B, Fig. 2), which is a characteristic feature of uranyl compounds [22]. DFT simulations, using polarisation along the trans-dioxo plane, have previously shown that Feature $\mathrm{B}$ is attributable to multiple scattering contributions from the uranyl group $\left([\mathrm{O}=\mathrm{U}=\mathrm{O}]^{2+}\right)[23]$. Multiple scattering contributions from this plane have also been shown to exhibit a peak at the white line. Likewise, polarisation along the equatorial plane demonstrated that the broad feature at $17,212.0 \mathrm{eV}$ (Feature C, Fig. 2) is attributable to multiple scattering from equatorial bonding $\left(\mathrm{U}-\mathrm{O}_{\mathrm{eq}}\right)$ contributions [24]. Feature $\mathrm{B}$ was present in the amorphous phase spectra $\left(250-500^{\circ} \mathrm{C}\right)$, which indicates that its molecular structure likely also contains a uranyl group. The presence of uranyl bonding in the amorphous phase is in agreement with previous findings [2, 25]. Interestingly, Feature B had shifted $\sim 1 \mathrm{eV}$ lower in energy from the metastudtite precursor, which suggests an increase in the length of the uranyl bond in the amorphous phase, according to the Natoli relation (Eq. 1) [26]

$\Delta E \times R^{2}=k$

where $\Delta E$ is the difference between resonance energies from axial $\mathrm{O}_{\mathrm{ax}}$ and equatorial $\mathrm{O}_{\mathrm{eq}}$ and the white line, $R$ is the $\mathrm{U}-\mathrm{O}$ bond length and $k$ is a constant. The calculated bond lengths are tabulated in Table 1. Further, a direct relationship exists between the intensity of Feature $\mathrm{C}$ and equatorial $\mathrm{U}-\mathrm{O}_{\mathrm{eq}}$ bond length, as shown in Table 1 [27]. In the spectra

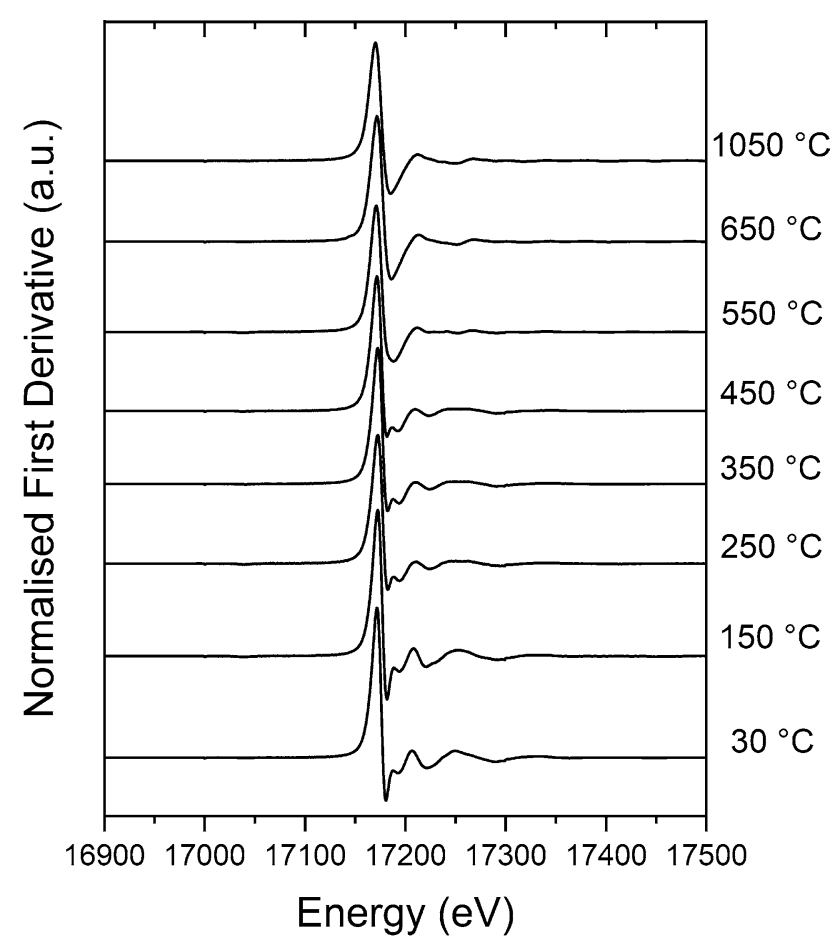

peak. Feature $\mathrm{C}$ arrises from contributions of $\mathrm{U}-\mathrm{O}_{\text {eq }}$ scattering. The spectra in the first derivative (right) were used to calculate values of the threshold energy $\left(E_{0}\right)$ 
Table 1 Tabulated $\mathrm{U}-\mathrm{O}_{\mathrm{eq}}$ bond lengths from XANES analysis, including metastudtite $\left(150^{\circ} \mathrm{C}\right)$ into the amorphous phase $\left(250-450{ }^{\circ} \mathrm{C}\right)$, compared to literature values obtained from EXAFS [25]

\begin{tabular}{|c|c|c|c|c|}
\hline Heating temperature & U-O Bond type & $\begin{array}{l}\text { Maximum of } \\
\text { XANES feature C } \\
(\mathrm{eV})\end{array}$ & $\begin{array}{l}\text { Estimated } \mathrm{U}-\mathrm{O}_{\mathrm{eq}} \\
\text { bond length } \\
\text { (XANES) }\end{array}$ & $\begin{array}{l}\mathrm{U}-\mathrm{O}_{\mathrm{eq}} \text { bond } \\
\text { length (EXAFS) } \\
{[25]}\end{array}$ \\
\hline Metastudtite $\left(150^{\circ} \mathrm{C}\right)$ & $\mathrm{U}-\mathrm{O}_{\mathrm{eq}}$ & $17,211.9$ & 2.45 & $2.34 \pm 0.02$ \\
\hline Am-phase $\left(250^{\circ} \mathrm{C}\right)$ & $\mathrm{U}-\mathrm{O}_{\mathrm{eq}}$ & $17,212.9$ & 2.44 & $2.28 \pm 0.02$ \\
\hline Am-phase $\left(350^{\circ} \mathrm{C}\right)$ & $\mathrm{U}-\mathrm{O}_{\mathrm{eq}}$ & $17,212.9$ & 2.44 & $2.32 \pm 0.02$ \\
\hline Am-phase $\left(450^{\circ} \mathrm{C}\right)$ & $\mathrm{U}-\mathrm{O}_{\mathrm{eq}}$ & $17,213.9$ & 2.43 & $2.30 \pm 0.04$ \\
\hline
\end{tabular}

at $250-500{ }^{\circ} \mathrm{C}$, Feature $\mathrm{C}$ was lower in intensity than in the studtite/metastudtite precursor spectra, and situated at a higher energy of $17,275.0 \mathrm{eV}$, suggesting that the equatorial $\mathrm{U}-\mathrm{O}_{\text {eq }}$ bonds are shorter in the amorphous phase structure. The discrepancy between estimated $\mathrm{U}-\mathrm{O}_{\text {eq }}$ bond lengths from XANES and those calculated in EXAFS is likely due to the difficulty in determining the peak position of the broad Feature C. The $\alpha-\mathrm{UO}_{3}$ sample $\left(550{ }^{\circ} \mathrm{C}\right)$ exhibited a broader white line feature than its precursors, situated at a higher energy of $17,178.7 \mathrm{eV}$. The reason for this broadening has not been determined experimentally but has previously been attributed to the shortening of equatorial $\mathrm{U}-\mathrm{O}_{\text {eq }}$ bonds [24]. As Feature $\mathrm{C}$ was still present at this temperature, it is evident that $\mathrm{U}-\mathrm{O}_{\text {eq }}$ bonding was retained on heating, so the broadening of the white line might be explained by the change of some of these bond lengths from 2.40 to $2.02 \AA$ in studtite and $\alpha-\mathrm{UO}_{3}$, respectively $[8,9]$. Shoulder peak B was not observed in the spectrum of $\alpha-\mathrm{UO}_{3}$, implying the loss of uranyl bonding. This was expected, as $\alpha-\mathrm{UO}_{3}$ is known to possess longer uranyl-like bond lengths of $2.08 \AA$ rather than the 1.7-1.9 $\AA$ of a typical axial uranyl bond [28]. It is likely that the local structure of $\alpha-\mathrm{U}_{3} \mathrm{O}_{8}\left(650\right.$ and $\left.1050{ }^{\circ} \mathrm{C}\right)$ does not differ greatly from its precursor, as only Feature A broadens, producing a similar absorption spectrum to $\alpha-\mathrm{UO}_{3}$.

It has been reported that using only the white line to calculate the threshold energy $\left(E_{0}\right)$, and subsequently, the oxidation state, is problematic for actinyl oxo cation $\left(\mathrm{AnO}_{2}\right)^{2+}$ compounds [24]. The white line does not reflect atomic character alone and is instead, the product of a combination of geometric and electronic effects. Therefore, the maximum of the first inflection in the normalised first derivative was used to calculate $E_{0}$ values and, subsequently, the predicted oxidation state of the central $U$ atom (Table 2). A general trend of gradually decreasing $E_{0}$ energy from $17,171.5$ to $17,170.0 \mathrm{eV}$ was found with increasing temperature, which implies a tendency to lower $\mathrm{U}$ oxidation state in $\alpha-\mathrm{U}_{3} \mathrm{O}_{8}$. Considering the previously reported mixed U(VI/V) oxidation state in $\alpha-\mathrm{U}_{3} \mathrm{O}_{8}$, it was expected that a lower value of $E_{0}$ would be obtained at higher calcination temperatures of studtite [29].

\section{Fourier transform infrared spectroscopy}

The infrared spectra of studtite (labelled $30^{\circ} \mathrm{C}$ in Fig. 3) and metastudtite $\left(150{ }^{\circ} \mathrm{C}\right)$ show a prominent band at $916 \mathrm{~cm}^{-1}$ and a broader band at around $3500 \mathrm{~cm}^{-1}$. These features correspond to the uranyl ion antisymmetric stretch, $\nu_{3}\left(\mathrm{UO}_{2}\right)^{2+}$, and the hydroxide stretch (between two water molecules), $\nu(\mathrm{OH})_{\text {water }}$, modes, respectively. In studtite, the $\nu(\mathrm{OH})_{\text {water }}$ peak was accompanied by a second broader feature at $3160 \mathrm{~cm}^{-1}$ but this second feature becomes weaker and shifts in position to around $3100 \mathrm{~cm}^{-1}$ during dehydration to metastudtite.

Decomposition of metastudtite into the amorphous phase results in the $\nu_{3}\left(\mathrm{UO}_{2}\right)^{2+}$ band shifting to $\sim 938 \mathrm{~cm}^{-1}$ with a second band becoming observable at $\sim 842 \mathrm{~cm}^{-1}$. Splitting of the single band into two results from the symmetric and asymmetric vibrational modes of the uranyl bond, unseen in spectra at lower temperatures, suggesting that the uranyl ion is not linear in the amorphous phase.
Table 2 Tabulated values of the white line position $(\mathrm{eV})$ from the normalised absorption spectra for studtite $\left(30^{\circ} \mathrm{C}\right)$. The threshold energy, $E_{0}(\mathrm{eV})$, is also tabulated, and was obtained from the maximum of the first inflection point of the first derivative

\begin{tabular}{llll}
\hline Calcination temperature $\left({ }^{\circ} \mathrm{C}\right)$ & White line $(\mathrm{eV})$ & $\begin{array}{l}\text { First derivative, } \mathrm{E}_{0} \\
(\mathrm{eV})\end{array}$ & Oxidation state \\
\hline 30 (Room temperature) & $17,177.2$ & $17,171.5$ & $\mathrm{U}(\mathrm{VI})$ \\
150 & $17,177.3$ & $17,171.4$ & $\mathrm{U}(\mathrm{VI})$ \\
250 & $17,177.9$ & $17,171.0$ & $\mathrm{U}(\mathrm{VI})$ \\
350 & $17,177.8$ & $17,171.0$ & $\mathrm{U}(\mathrm{VI})$ \\
450 & $17,177.9$ & $17,170.8$ & $\mathrm{U}(\mathrm{VI})$ \\
550 & $17,178.7$ & $17,170.4$ & $\mathrm{U}(\mathrm{VI})$ \\
650 & $17,178.6$ & $17,170.2$ & $\mathrm{U}(\mathrm{V} / \mathrm{VI})$ \\
1050 & $17,179.0$ & $17,170.0$ & $\mathrm{U}(\mathrm{V} / \mathrm{VI})$ \\
\hline
\end{tabular}




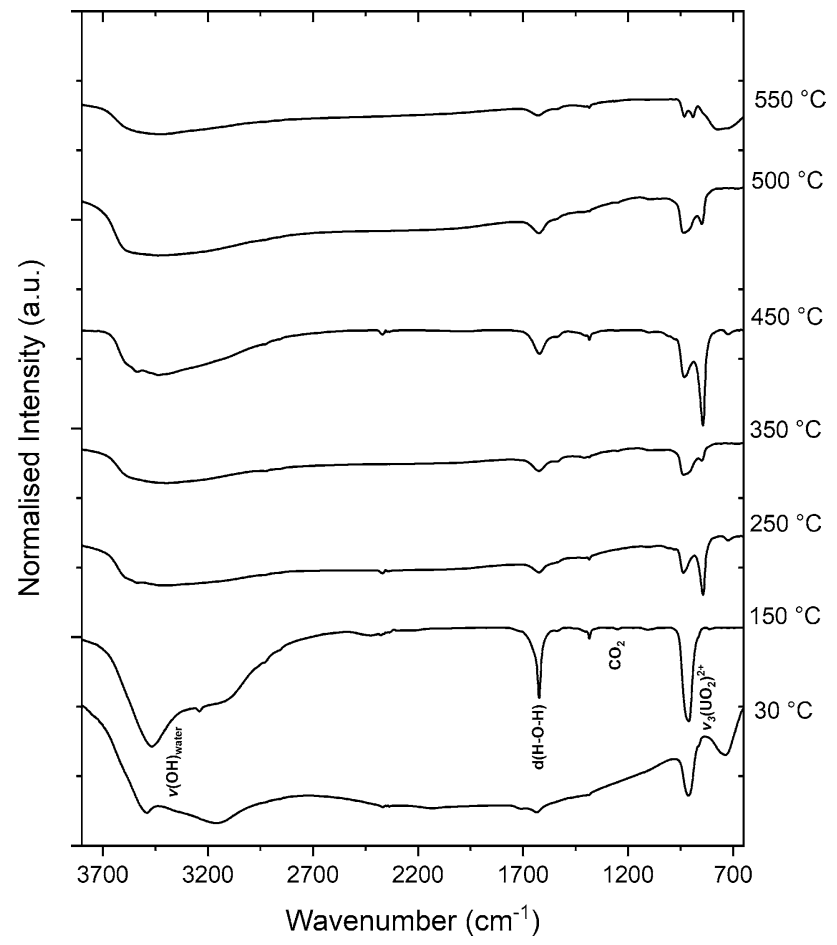

Fig. 3 FTIR spectra of studtite $\left(30^{\circ} \mathrm{C}\right)$ and heated studtite samples

This further suggests the presence of the uranyl ion in the structure of the amorphous compound, consistent with results obtained by XANES. The features corresponding to $\mathrm{v}(\mathrm{O}-\mathrm{H})$ were broader and any trace of the paired band at $3160 \mathrm{~cm}^{-1}$ is lost at these temperatures.

Further decomposition beyond the amorphous phase results in the transformation of $\alpha-\mathrm{UO}_{3}$ [30]. The IR spectrum of the sample heated to $550{ }^{\circ} \mathrm{C}$ shows weak intensity features in the uranyl and water region. The crystal structure of $\alpha-\mathrm{UO}_{3}$ does not contain uranyl bonding (Fig. 1, right) but has been known to mimic uranyl IR features due to uranium vacancies creating strong, uranyl-like absorptions in the super-lattice [28, 31].

Most IR spectra contained additional bands (Fig. 3). The weak features positioned at $1386 \mathrm{~cm}^{-1}$ are attributed to $\mathrm{CO}_{2}$, as previously reported [32]. It is plausible that $\mathrm{CO}_{2}$ might have adsorbed onto the surface of the samples prior to measurement. The band at $1622 \mathrm{~cm}^{-1}$ is attributed to the water bending mode, $d(\mathrm{H}-\mathrm{O}-\mathrm{H})$, which generally decreases in IR signal strength during thermal decomposition. However, observation of this mode in all our IR spectra suggests that all the samples display some hygroscopic characteristics [2]. The relatively high background level present across the whole spectral range for studtite $\left(30^{\circ} \mathrm{C}\right.$, Fig. 3) could be an indication that the crystal structure was not thermally stabilised across the whole (bulk) sample.



Fig. 4 Raman spectra of studtite $\left(30^{\circ} \mathrm{C}\right)$ and heated studtite

\section{Raman spectroscopy}

The Raman spectra for each material explored in this study are shown in Fig. 4, over the spectral range $1000-50 \mathrm{~cm}^{-1}$, and clearly show significant changes in the spectrum enabling all the thermal decomposition products of studtite to be differentiated from each other. The spectra collected at $30^{\circ} \mathrm{C}$ (studtite), $100{ }^{\circ} \mathrm{C}$ and $150{ }^{\circ} \mathrm{C}$ (both metastudtite) display two sharp, intense peaks characteristic of the symmetric stretch of the peroxide anion, $\nu_{1}(\mathrm{O}-\mathrm{O})$, and uranyl ion, $\nu_{1}\left(\mathrm{UO}_{2}\right)^{2+}$. Within this dehydration region, the $\nu_{1}(\mathrm{O}-\mathrm{O})$ single peak remained at roughly the same position $\left(865-869 \mathrm{~cm}^{-1}\right)$ whereas the single $\nu_{1}\left(\mathrm{UO}_{2}\right)^{2+}$ peak at $820 \pm 3 \mathrm{~cm}^{-1}$ (with the error taken as the variation in peak position) is gradually replaced by another at $832 \mathrm{~cm}^{1}$. This is in good agreement with other Raman studies exploring the dehydration of studtite to metastudtite [2, 32]. The observed shift in the $\nu_{1}\left(\mathrm{UO}_{2}\right)^{2+}$ mode suggests that the studtite to metastudtite transformation is accompanied by a slight reduction in the uranyl $\mathrm{U}=\mathrm{O}$ bond length, $d_{U=O}$, from 1.779 to $1.773 \pm 0.003 \AA$ (using Eq. 2 as derived by Bartlett and Cooney (1989)), where error was calculated as the maximum and minimum bounds within a range of $\pm 3 \mathrm{~cm}^{-1}$ [33]. 
$d_{U=O}(\AA)=106.5\left[v_{1}\left(U O_{2}\right)^{2+}\left(\mathrm{cm}^{-1}\right)\right]^{-2 / 3}+0.575$

Other features observed in the studtite and metastudtite Raman spectra (30 to $150{ }^{\circ} \mathrm{C}$ in Fig. 4) were all relatively weak in intensity with peak positions around $360-350$, $300-290,263,236,192-187,154$ and $65-59 \mathrm{~cm}^{-1}$. The uranyl symmetric bending mode, $\nu_{2}\left(\mathrm{UO}_{2}\right)^{2+}$, would be expected in this region $[2,32]$.

Comparisons with other uranyl oxides, such as becquerelite $\left(\mathrm{Ca}\left(\mathrm{UO}_{2}\right)_{6} \mathrm{O}_{4}(\mathrm{OH})_{6} \cdot 8\left(\mathrm{H}_{2} \mathrm{O}\right)\right)$, billietite $\left(\mathrm{Ba}\left(\mathrm{UO}_{2}\right)_{6} \mathrm{O}_{4}(\mathrm{O}\right.$ $\left.\mathrm{H})_{6} \cdot 8\left(\mathrm{H}_{2} \mathrm{O}\right)\right)$, curite $\left(\mathrm{Pb}_{3+x}\left(\mathrm{UO}_{2}\right)_{4} \mathrm{O}_{4+\mathrm{x}}(\mathrm{OH})_{3-x}\left(\mathrm{H}_{2} \mathrm{O}\right)_{2}\right)$, schoepite $\left(\left(\mathrm{UO}_{2}\right)_{8} \mathrm{O}_{2}(\mathrm{OH})_{12} \cdot 12\left(\mathrm{H}_{2} \mathrm{O}\right)\right)$ and vandendriesscheite $\left(\mathrm{Pb}_{1.57}\left(\mathrm{UO}_{2}\right)_{10} \mathrm{O}_{6}(\mathrm{OH})_{11} \cdot 11\left(\mathrm{H}_{2} \mathrm{O}\right)\right)$ suggests the $\nu_{2}\left(\mathrm{UO}_{2}\right)^{2+}$ mode could also be attributed to the two bands observed in this study at 263 and $236 \mathrm{~cm}^{-1}$ [34]. However, more exhaustive computational Raman modelling studies are required to confirm this assignment.

Decomposition of the sample from 150 to $250{ }^{\circ} \mathrm{C}$ significantly changes the Raman spectra indicating the transition between metastudtite and the amorphous phase [35]. The $\nu_{1}(\mathrm{O}-\mathrm{O})$ peak disappears whereas the $\nu_{1}\left(\mathrm{UO}_{2}\right)^{2+}$ feature becomes significantly broader and shifts slightly to $838 \pm 3 \mathrm{~cm}^{-1}$. The disappearance of the $\nu_{1}(\mathrm{O}-\mathrm{O})$ peak indicates the loss of the peroxo bond in the amorphous phase, whereas findings by DFT simulations, EXAFS and neutron diffraction have shown interatomic $\mathrm{O}-\mathrm{O}$ distances of a peroxo bond [10, 11, 25]. This is not implausible, as Raman spectroscopy is sensitive to chemical bonding, whereas $\mathrm{X}$-ray absorption and neutron diffraction give an indication of interatomic distance based on scattering events. On the other hand, the peroxo group may contribute to the broad peak at $838 \mathrm{~cm}^{-1}$ by shifting to lower wavenumbers. However, this seems unlikely, as the $\mathrm{O}-\mathrm{O}$ distance has been shown by EXAFS to increase with temperature of annealing, whereas a shift to lower wavenumber would imply the contrary [25]. At the same temperature, a new, broad peak at
$757 \mathrm{~cm}^{-1}$ appears, but it is not assigned. However, when this feature is hypothetically attributed as $\nu_{1}\left(\mathrm{UO}_{2}\right)^{2+}$ and applied to Eq. 2, the resultant $d_{U=O}$ values of $1.85-1.87 \AA$ correspond well with the previous $\mathrm{U}-\mathrm{O}_{\mathrm{ax}}(2)$ axial bond length (1.83-1.86 А; Table 3) determined in EXAFS. This would suggest that the uranyl unit might consist of two axial $\mathrm{U}=\mathrm{O}$ bond lengths, $\mathrm{U}-\mathrm{O}_{\mathrm{ax}}(1)$ and $\mathrm{U}-\mathrm{O}_{\mathrm{ax}}(2)$. Further dehydration up to $500{ }^{\circ} \mathrm{C}$ results in the $\nu_{1}(\mathrm{U}-\mathrm{O})$ mode shifting to higher wavenumbers and its peak intensity reducing. The new peak at $757 \mathrm{~cm}^{-1}$ remains at roughly the same position but, with increasing temperature, a second peak at around $700 \mathrm{~cm}^{-1}$ grows in intensity.

The Raman spectra alter again between 500 and $550{ }^{\circ} \mathrm{C}$ (Fig. 5) revealing decomposition into $\alpha-\mathrm{UO}_{3}$ [10]. The crystal structure of $\alpha-\mathrm{UO}_{3}$ does not contain uranyl bonding (Fig. 1); however, the crystal sheets present in $\alpha-\mathrm{UO}_{3}$ are known to mimic uranyl features due to uranium vacancies creating strong, uranyl-like absorptions in the superlattice [31]. The pseudo $v_{1}\left(\mathrm{UO}_{2}\right)^{2+}$ mode, now $\sim 850 \mathrm{~cm}^{-1}$, reduces to just above the apparatus detection limit. The broad double peak feature observed for the amorphous phase is replaced by a series of broad peaks with weak signal intensity centred at around 646, 575, 495, 393, $253 \mathrm{~cm}^{-1}$.

\section{Fluorescence spectroscopy}

Fluorescence excitation and emission spectra were collected for the samples heated up to $550{ }^{\circ} \mathrm{C}$ (Fig. 5). With an excitation wavelength $\left(\lambda_{e x}\right)$ of $375.6 \mathrm{~nm}$, three common features were observed in the emission spectra: a single peak at around $483 \mathrm{~nm}$, a broad multiple peak 490 to $510 \mathrm{~nm}$ and an asymmetrically shaped peak centred around $555 \mathrm{~nm}$. As the temperature increases, the signal of all three fluorescence emission features decreases at roughly the same rate. However, no differentiating features were observed between studtite, metastudtite, the amorphous phase or $\alpha-\mathrm{UO}_{3}$.

Table 3 Axial uranyl bond lengths, $\mathrm{U}-\mathrm{O}_{\mathrm{ax}}(1)$ and $\mathrm{U}-\mathrm{O}_{\mathrm{ax}}(2)$, from XANES and Raman spectroscopy, compared to literature values obtained from EXAFS [25]

\begin{tabular}{|c|c|c|c|c|c|}
\hline Heating temperature & $\mathrm{U}=\mathrm{O}$ Bond & $\begin{array}{l}\mathrm{U}=\mathrm{O}_{\mathrm{ax}} \text { bond length }(\AA ; \\
\text { XANES })\end{array}$ & $\begin{array}{l}\mathrm{U}=\mathrm{O}_{\mathrm{ax}} \text { Raman shift } \\
\left(\mathrm{cm}^{-1}\right)\end{array}$ & $\begin{array}{l}\mathrm{U}=\mathrm{O}_{\mathrm{ax}} \text { bond length } \\
(\mathrm{A} ; \text { Raman })\end{array}$ & $\begin{array}{l}\mathrm{U}=\mathrm{O}_{\mathrm{ax}} \text { bond } \\
\text { length }(\AA ; \\
\text { EXAFS })^{25}\end{array}$ \\
\hline \multirow[t]{2}{*}{ Metastudtite $\left(150^{\circ} \mathrm{C}\right)$} & $\mathrm{U}-\mathrm{O}_{\mathrm{ax}}(1)$ & N/A & 832 & $1.779 \pm 0.003$ & $1.77 \pm 0.01$ \\
\hline & $\mathrm{U}-\mathrm{O}_{\mathrm{ax}}(2)$ & 1.82 & N/A & N/A & $1.81 \pm 0.01$ \\
\hline \multirow[t]{2}{*}{ Am-phase $\left(250^{\circ} \mathrm{C}\right)$} & $\mathrm{U}-\mathrm{O}_{\mathrm{ax}}(1)$ & N/A & 838 & $1.773 \pm 0.003$ & $1.80 \pm 0.01$ \\
\hline & $\mathrm{U}-\mathrm{O}_{\mathrm{ax}}(2)$ & 1.84 & 760 & $1.854 \pm 0.003$ & $1.83 \pm 0.01$ \\
\hline \multirow[t]{2}{*}{ Am-phase $\left(350^{\circ} \mathrm{C}\right)$} & $\mathrm{U}-\mathrm{O}_{\mathrm{ax}}(1)$ & N/A & 838 & $1.773 \pm 0.003$ & $1.80 \pm 0.01$ \\
\hline & $\mathrm{U}-\mathrm{O}_{\mathrm{ax}}(2)$ & 1.85 & 760 & $1.854 \pm 0.003$ & $1.86 \pm 0.01$ \\
\hline \multirow[t]{2}{*}{ Am-phase $\left(450^{\circ} \mathrm{C}\right)$} & $\mathrm{U}-\mathrm{O}_{\mathrm{ax}}(1)$ & N/A & 838 & $1.773 \pm 0.003$ & $1.80 \pm 0.01$ \\
\hline & $\mathrm{U}-\mathrm{O}_{\mathrm{ax}}(2)$ & 1.86 & 750 & $1.865 \pm 0.003$ & $1.85 \pm 0.02$ \\
\hline
\end{tabular}





Fig. 5 Fluorescence excitation (left) and emission spectra (right) of studtite and heated studtite samples where $\lambda_{e m}$ and $\lambda_{e x}$ was held between 506.7 to $510.3 \mathrm{~nm}$ and $375.6 \mathrm{~nm}$, respectively

Fluorescence excitation spectra were collected with an emission wavelength $\left(\lambda_{e m}\right)$ corresponding to the highest band in the emission spectra (i.e. between 506.7 and $510.3 \mathrm{~nm}$ ). Common fluorescence features were also observed in the excitation spectra (Fig. 5, left). These appear as single bands at around 375, 394, 415, 432 and $442 \mathrm{~nm}$. The three lowest temperature excitation spectra also display a band centred around $488 \mathrm{~nm}$ but this feature shifts outside the upper spectral boundary region. As with the emission features, the fluorescence strength of these common features decreases at roughly the same rate with increasing temperature.

\section{Reaction of the amorphous phase with water}

Reaction of the amorphous phase (where studtite was heated to $250{ }^{\circ} \mathrm{C}$ ) with deionised water formed metaschoepite, $\left(\left[\left(\mathrm{UO}_{2}\right)_{4} \mathrm{O}(\mathrm{OH})_{6}\right]\left(\mathrm{H}_{2} \mathrm{O}\right)_{5}\right.$; Fig. 6), and was confirmed by XRD (Fig. 7) [36, 37]. During the reaction of the amorphous phase with water, a gas was released as observed by effervescence. The metaschoepite crystal structure consists of uranyl pentagonal bipyramid sheets, intercalated with water molecules [6]. Metaschoepite has previously been formed by dissolution of lanthanum hydroxide (or oxide) in a solution of uranyl ions until precipitation at high $\mathrm{pH}$, in addition to this method [10, 35, 38]. Schoepite, $\left(\left(\mathrm{UO}_{2}\right)_{4} \mathrm{O}(\mathrm{OH})_{6}\left(\mathrm{H}_{2} \mathrm{O}\right)_{6}\right)$, is also known to precipitate during the weathering of uraninite and the oxidation-hydration of spent nuclear fuel. It then partially dehydrates into metaschoepite through the loss of water molecules from the interlayers, which can happen at room temperature in air [37-46]. By further understanding the reactivity of the amorphous phase, a more complete knowledge base of synthetic routes and their products can be built.

The hydration product of the amorphous phase was indexed as metaschoepite (ICSD \#280,386; Fig. 7) by XRD. The pattern for metaschoepite is similar to schoepite, so comparison of our product to both patterns was necessary. Metaschoepite can most easily be distinguished from schoepite by the presence of the (113) reflection at $2 \theta=20^{\circ}$, which is absent in the latter. The degree of overlapping of the (004), (204) and (400) reflections matches closer to those observed in metaschoepite than schoepite. Between $2 \theta=30$ and $35^{\circ}$, reflections in the (115), (243) and (061) planes are also seen, which are not present in the 



Fig. 6 The crystal structure of metaschoepite, showing the layers of U-O bonds separated by water (left, viewed along the b-axis), and the U-O bonding network (right, viewed along the a-axis) [36]. The elements $\mathrm{U}, \mathrm{O}$ and $\mathrm{H}$ are shown in blue, red and white, respectively

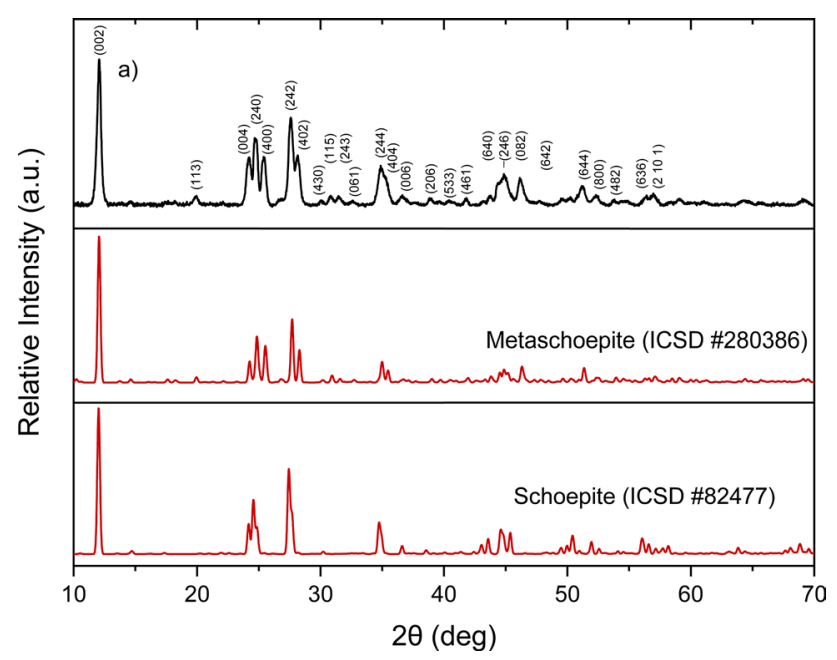

Fig. 7 XRD pattern for the product formed by the reaction of the amorphous phase (studtite heated to $250{ }^{\circ} \mathrm{C}$ ) with water. Reference patterns simulated from crystallographic data of metaschoepite and schoepite are included [36, 37]

XRD pattern of schoepite. From these observations, it is deduced that the amorphous phase undergoes hydration to form crystalline metaschoepite and has been distinguished from schoepite.

\section{Thermal decomposition mechanism of studtite}

The range of complementary analytical techniques employed in this study has extracted more information regarding the material properties of the thermal decomposition products of studtite. In particular, significant changes in the overall Raman spectra (Fig. 4) coincided with the three decomposition stages detected by TGA-MS analysis (Supplementary Information, Figure S2) enabling each product to be differentiated. More information on material properties was extracted using the other techniques; for example, observations of the antisymmetric and symmetric uranyl stretch modes in IR spectra for the amorphous phase (Fig. 3) suggests that the uranyl ion deviates from linearity during the transformation between metastudtite and $\alpha-\mathrm{UO}_{3}$ while XANES findings indicate that uranium remains in the $\mathrm{U}(\mathrm{VI})$ oxidation state until $\alpha-\mathrm{UO}_{3}$ decomposes into $\mathrm{U}_{3} \mathrm{O}_{8}$ at temperatures above $550{ }^{\circ} \mathrm{C}$. From the above results, supplementary information and the known crystal structures of studtite and $\alpha-\mathrm{UO}_{3}$ (Fig. 1), a proposed thermal decomposition mechanism for studtite was obtained and is shown in Fig. 8.

The dehydration of studtite into metastudtite through loss of water molecules situated between the studtite chains becomes detectable by TGA-MS above $50{ }^{\circ} \mathrm{C}$ (Supplementary Information, Figure S2). It is plausible that studtite dehydrates into its meta-form above room temperature in a similar manner to schoepite, but this could 
Fig. 8 Proposed two-dimensional schematic for the mechanism of studtite decomposition into $\alpha-\mathrm{UO}_{3}$



By 535 C, $\alpha$-uranium-trioxide is formed.

At higher temperatures, the structure starts fusing together along all plane directions (including in and out of the page).
Above $150 \mathrm{C}$, metastudtite decomposes into the amorphous phase. Here, bonded water, the peroxide and some axial U-O bonds begin to break.

By $100 \mathrm{C}$, metastudite is formed.

\section{Studtite.}

Decomposition of metastudtite into the amorphous phase was detected by gaseous water and oxygen mass traces in the TGA-MS data around $200{ }^{\circ} \mathrm{C}$ (Supplementary Information, Figure S2) and through the loss of the peroxide Raman vibration from $250{ }^{\circ} \mathrm{C}$ (Fig. 4). These observations can be 
explained by bonds breaking between the water molecules and the central uranium ion in the uranyl hexagonal bipyramid. The space created by the water molecule voids results in a relaxation of the $(\mathrm{O}=\mathrm{U}=\mathrm{O})^{2+}$ bond angle which breaks the peroxide bond (Fig. 8). The change in the $(\mathrm{O}=\mathrm{U}=\mathrm{O})^{2+}$ bond angle could explain the observation of both the antisymmetric and symmetric stretch uranyl modes in the IR spectra (Fig. 3) if the relaxation rate varies across the bulk sample. It is plausible that the change in these bond angles may vary the bond length of the uranyl ion resulting in the broad Raman peaks situated at 757 and $700 \mathrm{~cm}^{-1}$ during the thermal decomposition stage of the amorphous phase. This would preserve the oxidation state of the central uranium ion as U(VI) in accordance with the XANES results (Fig. 2).

The TGA-MS oxygen peak at $200{ }^{\circ} \mathrm{C}$ (Supplementary Information, Figure S2) is likely to be due to the breaking of some of the axial $\mathrm{U}-\mathrm{O}$ bonds, represented by the oxygen atoms aligned in and out of the page in Fig. 8. A second feature in the oxygen mass trace was observed in the TGA-MS data at around $520{ }^{\circ} \mathrm{C}$ (Supplementary Information, Figure S2) which coincides with the three-dimensional collapse of the original studtite chains in the amorphous phase; these fuse together to begin the formation of the $\alpha-\mathrm{UO}_{3}$ sheets (Fig. 1). It is possible that the second oxygen TGA-MS feature is caused by trapped oxygen atoms (from the lower temperature breaking of some axial $\mathrm{U}=\mathrm{O}$ bonds) being released during the three-dimensional collapse. However, computational studies are required to confirm this hypothesis. By $535^{\circ} \mathrm{C}$, the structural collapse is completed to form $\alpha-\mathrm{UO}_{3}$.

\section{Conclusion}

XANES, FTIR, Raman and fluorescence spectroscopy analyses were performed to interpret the thermal decomposition of studtite, with emphasis on characterising the amorphous phase. XANES analysis showed a generally decreasing trend in the threshold energy, $E_{0}$, with increasing calcination temperature. The compounds heated up to $550{ }^{\circ} \mathrm{C}$ are $\mathrm{U}(\mathrm{VI})$ (i.e. studtite to $\alpha-\mathrm{UO}_{3}$ ), and a gradual transition to mixed $\mathrm{U}(\mathrm{V} / \mathrm{VI})$ oxidation state occurred above $550{ }^{\circ} \mathrm{C}$, where $\alpha-\mathrm{UO}_{3}$ decomposes into $\mathrm{U}_{3} \mathrm{O}_{8}$. The first reported fluorescence excitation and emission spectra for these compounds revealed a general signal decrease with increasing temperature, but the individual decomposition products could not be distinguished.

Extraction of some structural information for the amorphous phase suggested the presence of a uranyl group $\left(\mathrm{UO}_{2}\right)^{2+}$ based on the broad shoulder XANES feature (Feature B) situated at $17,190 \mathrm{eV}$ and the observation of $\nu_{3}\left(\mathrm{UO}_{2}\right)^{2+}$ and $\nu_{1}\left(\mathrm{UO}_{2}\right)^{2+}$ modes at 938 and $838 \mathrm{~cm}^{-1}$ in the FTIR and Raman data, respectively. The XANES white line feature (Feature A) was broader in the spectra of the amorphous phase compounds, indicating the presence of longer uranyl bonding than those in metastudtite. This increase in uranyl bond length between 1.77 and $1.87 \AA$ was quantified by the application of the Natoli relation and Bartlett and Cooney equation in the XANES and Raman analysis, respectively. The interatomic distance in the equatorial $\mathrm{U}-\mathrm{O}_{\text {eq }}$ bonds is believed to shorten with increased temperature based on the shift in the XANES feature (Feature C) to higher energy and lower intensity from metastudtite to the amorphous phase. No Raman peak could be attributed to the peroxo $\mathrm{O}-\mathrm{O}$ bond in the amorphous phase samples, suggesting the oxygen atoms are instead situated at an interatomic distance similar to that of a peroxo bond $(\sim 1.5 \AA)$, but without being chemically bonded. This study also reports a Raman spectrum of $\alpha-\mathrm{UO}_{3}$. Although $\alpha-\mathrm{UO}_{3}$ does not contain uranyl ions, pseudo uranyl features were observed in both the FTIR and Raman spectra.

The amorphous phase compound, when reacted with water, was found by XRD analysis to form metaschoepite. This is a significant confirmation of the hydrolysis of the amorphous compound, whereby the XRD pattern of the hydrolysis product, metaschoepite, was distinguished from the more hydrated schoepite.

A mechanism was proposed for the thermal decomposition of studtite to $\alpha-\mathrm{UO}_{3}$ based on our spectroscopic characterisation. In summary, the dehydration of studtite is believed to occur from around $50{ }^{\circ} \mathrm{C}$, with the compound completely dehydrated at $\sim 150^{\circ} \mathrm{C}$. Some axial $\mathrm{U}=\mathrm{O}$ bonds, all $\mathrm{O}-\mathrm{O}$ and $\mathrm{U}-\left(\mathrm{H}_{2} \mathrm{O}\right)$ bonds are broken between 150 and $500{ }^{\circ} \mathrm{C}$ before the uranyl-bearing chains bond together to form crystalline $\alpha-\mathrm{UO}_{3}$. To the best of our knowledge, this is the first proposed schematic mechanism of the thermal decomposition of studtite.

Supplementary file DOCX (391 KB)Supplementary Information The online version contains supplementary material available at (https:// doi.org/10.1007/s10967-021-07611-4).

Acknowledgements This research utilised the HADES/MIDAS facility and Henry Royce Institute at the University of Sheffield established with financial support from UKRI EPSRC and BEIS, under grant EP/ T011424/1 and EP/P02470X/1, and was supported in part by grants EP/ L015390/1, EP/S011935/1 and EP/P013600/1. ${ }^{47}$ Raman and TRLFS characterisation were supported by funding from the Engineering \& Physical Science Research Council project (number EP/S01019X/1TRANSCEND). The Raman and TRLFS apparatus are supported by capital grants from the Engineering and Physical Science Research Council (EP/M022749/1) and the Natural Environment Research Council (NERC/CC041), respectively. Acknowledgements are given to Mr John-William Brown, Mrs Sarah Heisig and Dr Carol Crean (all University of Surrey) for advice and support. Collection of the XAS data was performed under the approval of the Photon Factory Advisory Committee (Proposal No. 2017G187), with support from EPSRC under grant reference EP/P013600/1; the support of Yoshihiro Okamoto (JAEA) and Noriko Usami (KEK) during the experiment is gratefully acknowledged. (C) British Crown Owned Copyright 2020/ 
AWE. Published with the permission of the Controller of Her Britannic Majesty's Stationary Office.

Open Access This article is licensed under a Creative Commons Attribution 4.0 International License, which permits use, sharing, adaptation, distribution and reproduction in any medium or format, as long as you give appropriate credit to the original author(s) and the source, provide a link to the Creative Commons licence, and indicate if changes were made. The images or other third party material in this article are included in the article's Creative Commons licence, unless indicated otherwise in a credit line to the material. If material is not included in the article's Creative Commons licence and your intended use is not permitted by statutory regulation or exceeds the permitted use, you will need to obtain permission directly from the copyright holder. To view a copy of this licence, visit http://creativecommons.org/licenses/by/4.0/.

\section{References}

1. Guo X, Wu D, Xu H, Burns P, Navrotsky A (2016) Thermodynamic studies of studtite thermal decomposition pathways via amorphous intermediates $\mathrm{UO}_{3}, \mathrm{U}_{2} \mathrm{O}_{7}$, and $\mathrm{UO}_{4}$. $\mathrm{J}$ Nucl Mater 478:158-163. https://doi.org/10.1016/j.jnucmat.2016.06.014

2. Thomas R, Rivenet M, Berrier E, de I W, Arab M, Amaraggi D, Morel B, Abraham F (2017) Thermal decomposition of $\left(\mathrm{UO}_{2}\right) \mathrm{O}_{2}\left(\mathrm{H}_{2} \mathrm{O}\right)_{2} \cdot 2\left(\mathrm{H}_{2} \mathrm{O}\right)$ : Influence on structure, microstructure and hydrofluorination. J Nucl Mater 483:149-157. https://doi. org/10.1016/j.jnucmat.2016.11.009

3. Vitova T, Pidchenko I, Biswas S, Beridze G, Dunne P, Schild D, Wang Z, Kowalski P, Baker R (2018) Dehydration of the uranyl peroxide studtite, $\left[\mathrm{UO}_{2}\left(\eta^{2}-\mathrm{O}_{2}\right)\left(\mathrm{H}_{2} \mathrm{O}\right)_{2}\right] \cdot 2 \mathrm{H}_{2} \mathrm{O}$, affords a drastic change in the electronic structure: a combined $\mathrm{x}$-ray spectroscopic and theoretical analysis. Inorg Chem 57:1735-1743. https://doi. org/10.1021/acs.inorgchem.7b02326

4. Walshe A, Prüßmann T, Vitova T, Baker R (2014) An EXAFS and HR-XANES study of the uranyl peroxides [UO2( $22-\mathrm{O} 2)$ $(\mathrm{H} 2 \mathrm{O}) 2] \cdot \mathrm{nH} 2 \mathrm{O}(\mathrm{n}=0,2)$ and uranyl (oxy)hydroxide [(UO2)4O(OH)6]·6H2O. Dalton Trans 43:4400-4407. https:// doi.org/10.1039/C3DT52437J

5. Schwerdt I, Brenkmann A, Martinson S, Albrecht B, Heffernan S, Klosterman M, Kirkham T, Tasdizen T, McDonald L IV (2018) Nuclear proliferomics: a new field of study to identify signatures of nuclear materials as demonstrated on alpha- $\mathrm{UO}_{3}$. Talanta 186:433-444. https://doi.org/10.1016/j.talanta.2018.04.092

6. Burns PC (2005) $\mathrm{U}^{6+}$ minerals and inorganic compounds: insights into an expanded structural hierarchy of crystal structures. Can Mineral 43:1839-1894. https://doi.org/10.2113/gscan $\min .43 .6 .1839$

7. Hughes Kubatko KA, Helean KB, Navrotsky A, Burns PC (2003) Stability of peroxide-containing uranyl minerals. Science 302:1191-1193. https://doi.org/10.1126/science.1090259

8. Burns PC, Hughes KA (2003) Studtite, $\left[\left(\mathrm{UO}_{2}\right)\left(\mathrm{O}_{2}\right)\left(\mathrm{H}_{2} \mathrm{O}\right)_{2}\right]\left(\mathrm{H}_{2} \mathrm{O}\right)_{2}$ : The first structure of a peroxide mineral. Amer Mineral 88:11651168. https://doi.org/10.2138/am-2003-0725

9. Loopstra BO, Cordfunke EHP (1966) On the structure of $\alpha-\mathrm{UO}_{3}$. Recl Trav Ch Pays-Ba 85:135-142. https://doi.org/10.1002/ recl.19660850204

10. Odoh S, Shamblin J, Colla C, Hickam S, Lobeck H, Lopez R, Olds T, Szymanowski J, Sigmon G, Neuefeind J, Casey W, Lang M, Gagliardi L, Burns P (2016) Structure and reactivity of X-ray amorphous uranyl peroxide, $\mathrm{U}_{2} \mathrm{O}_{7}$. J Inorg Chem 55:3541-3546. https://doi.org/10.1021/acs.inorgchem.6b00017
11. Shields A, Miskowiec A, Niedziela J, Kirkegaard M, Maheshwari K, Ambrogio M, Kapsimalis R, Anderson B (2019) Shining a light on amorphous $\mathrm{u}_{2} \mathrm{O}_{7}$ : a computational approach to understanding amorphous uranium materials. Opt Mater 89:295-298. https://doi. org/10.1016/j.optmat.2019.01.040

12. N. Thompson, S O'Sullivan, R Howell, D Bailey, M Gilbert, N Hyatt (2021), Objective colour analysis from digital images as a nuclear forensic tool. Forensic Sci. Int. 319:110678. https://doi. org/10.1016/j.forsciint.2020.110678

13. Konishi H, Yokoya A, Shiwaku H, Motohashi H, Makita T, Kashihara Y, Hashimoto S, Harami T, Sasaki TA, Maeta H, Ohno H, Maezawa H, Asaoka S, Kanaya N, Ito K, Usami N, Kobayashi K (1996) Synchrotron radiation beamline to study radioactive materials at the Photon factory. Nucl Instrum Methods A372:322. https ://doi.org/10.1016/0168-9002(95)01241-9

14. Bearden JA, Burr AF (1967) Reevaluation of X-ray atomic energy levels. Rev Mod Phys 39(1):125

15. Ravel B, Newville M (2005) Athena, Artemis, Hephaestus: data analysis for X-ray absorption spectroscopy using IFEFFIT. J. Synchrotron Radiat. 12:537-541. https://doi.org/10.1107/S090904950 5012719

16. Origin (Pro), Version 2017. OriginLab Corporation, Northampton, MA, USA.

17. Lee WH, Crean C, Varcoe JR, Bance-Soualhi R (2017) A Raman spectro-microscopic investigation of ETFE-based radiationgrafted anion-exchange membranes. RSC Adv 7:47726-47737. https://doi.org/10.1039/C7RA09650J

18. Frankland VL, Milodowski A, Read D. Combined Raman and time-resolved laser fluorescence spectroscopy analysis of Sr-Rich meta-autunite samples. Appl. Geochem., Unpublished results (submitted).

19. Thompson NB, Gilbert MR, Hyatt NC (2020) Nuclear forensic signatures of studtite and $\alpha-\mathrm{UO}_{3}$ from a matrix of solution processing parameters. J Nucl Mat 544:152713. https://doi. org/10.1016/j.jnucmat.2020.152713

20. Weck P, Kim E, Jové-Colón C, Sassani D (2012) Structures of uranyl peroxide hydrates: a first-principles study of studtite and metastudtite. Dalton Trans 41:9748. https://doi.org/10.1039/ C2DT31242E

21. N. Thompson (2017) Forensic signatures of nuclear materials processing. Cranfield Online Research Data. https://doi.org/10.17862 /cranfield.rd.5585398.v1

22. Crean D, Corkhill C, Nicholls T, Tappero R, Collins J, Hyatt N (2015) Expanding the nuclear forensic toolkit: chemical profiling of uranium ore concentrate particles by synchrotron X-ray microanalysis. RSC Adv 5:87908-87918. https://doi.org/10.1039/ C5RA14963K

23. Fillaux C, Berthet J, Conradson S, Guilbaud P, Guillaumont D, Hennig C, Moisy P, Roques J, Simoni E, Shuh D, Tyliszczak T, Castro-Rodriguez I, Den Auwer C (2007) Combining theoretical chemistry and XANES multi-edge experiments to probe actinide valence states. CR Chim. 10:859-871. https://doi.org/10.1016/j. crci.2006.12.012

24. Den Auwer C, Simoni E, Conradson S, Madic C (2004) Investigating actinyl oxo cations by X-ray absorption spectroscopy. J Inorg Chem Eur. https://doi.org/10.1002/ejic.200300093

25. Thompson N, Middleburgh S, Evitts L, Gilbert M, Stennett M, Hyatt N (2020) Short communication on further elucidating the structure of amorphous $\mathrm{U}_{2} \mathrm{O}_{7}$ by extended X-ray absorption spectroscopy and DFT simulations. J Nucl Mater. https://doi. org/10.1016/j.jnucmat.2020.152476

26. Jollivet P, Auwer C, Simoni E (2002) Evolution of the uranium local environment during alteration of SON68 glass. J Nucl Mater 301:142-152. https://doi.org/10.1016/S0022-3115(01)00759-0 
27. Zhang L, Zhou J, Zhang J, Su J, Zhang S, Chen N, Jia Y, Li J, Wang Y, Wang J (2016) Extraction of local coordination structure in a low-concentration uranyl system by XANES. J Synchrotron Rad 23:758-768. https://doi.org/10.1107/S1600577516001910

28. Brincat N, Parker S, Molinari M, Allen G, Storr M (2014) Ab Initio investigation of the $\mathrm{UO}_{3}$ polymorphs: structural properties and thermodynamic stability. Inorg Chem 53:12253-12264. https:// doi.org/10.1021/ic500791m

29. Sanyal K, Khooha A, Das G, Tiwari M, Misra N (2016) Direct determination of oxidation states of uranium in mixed-valent uranium oxides using total reflection X-ray fluorescence X-ray absorption near-edge spectroscopy. Anal Chem 89:871-876. https ://doi.org/10.1021/acs.analchem.6b03945

30. Cordfunke E, Van Der Giessen A (1963) Pseudomorphic decomposition of uranium peroxide into $\mathrm{UO}_{3}$. J Inorg Nucl Chem 25:553-555. https://doi.org/10.1016/0022-1902(63)80240-7

31. Greaves C, Fender B (1972) The structure of $\alpha-\mathrm{UO} 3$ by neutron and electron diffraction. Acta Crystallograp Sect B Struct Crystallograp Crystal Chem 28:3609-3614. https://doi.org/10.1107/ S056774087200843X

32. Bastian S, Crump G, Griffth GP, Withnall R (2004) Raspite and studtite: Raman spectra of two unique minerals. J Raman Spectrosc 35:726-731. https://doi.org/10.1002/jrs.1176

33. Bartlett J, Cooney R (1989) On the determination of uraniumoxygen bond lengths in dioxouranium(VI) compounds by Raman spectroscopy. J Mol Struct 193:295-300. https://doi. org/10.1016/0022-2860(89)80140-1

34. Frost RL, Cejka J, Weier ML (2007) Raman spectroscopic study of the uranyl oxyhydroxide hydrates: becquerelite, billietite, curite, schoepite and vandendriesscheite. J Raman Spectrosc 38:460466. https://doi.org/10.1002/jrs.1669

35. Rey A, Casas I, Giménez J, Quiñones J, de Pablo J (2009) Effect of temperature on studtite stability: thermogravimetry and differential scanning calorimetry investigations. J Nucl Mater 385:467473. https://doi.org/10.1016/j.jnucmat.2008.12.045

36. Weller M, Light M, Gelbrich T (2000) Structure of uranium(VI) oxide dihydrate, $\mathrm{UO}_{3} \cdot 2 \mathrm{H}_{2} \mathrm{O}$; synthetic meta-schoepite $\left(\mathrm{UO}_{2}\right)_{4} \mathrm{O}(\mathrm{OH})_{6} \cdot 5 \mathrm{H}_{2} \mathrm{O}$. Act. Crystallogr. B. 56:577-583. https:// doi.org/10.1107/s0108768199016559

37. Plášil J (2018) The crystal structure of uranyl-oxide mineral schoepite, $\left[\left(\mathrm{UO}_{2}\right)_{4} \mathrm{O}(\mathrm{OH})_{6}\right]\left(\mathrm{H}_{2} \mathrm{O}\right)_{6}$, revisited. J Geosci 63:65-73. https://doi.org/10.3190/jgeosci.252
38. Hoekstra HR, Siegel S (1973) The uranium trioxide-water system. J Inorg Nucl Chem 35:761-779. https://doi.org/10.1016/00221902(73)80444-0

39. Finch R, Ewing R (1992) The corrosion of uraninite under oxidising conditions. J Nucl Mater 190:133-156. https://doi. org/10.1016/0022-3115(92)90083-W

40. Wronkiewicz D, Bates J, Wolf S, Buck E (1996) Ten year results from unsaturated drip tests with $\mathrm{UO}_{2}$ at $90^{\circ} \mathrm{C}$. J Nucl Mater 238:78-95. https://doi.org/10.1016/S0022-3115(96)00383-2

41. Janeczek J, Ewing R, Oversby V, Werme L (1996) Uraninite and $\mathrm{UO}_{2}$ in spent nuclear fuel: a comparison. J Nucl Mater 238:121130. https://doi.org/10.1016/S0022-3115(96)00345-5

42. P.C. Burns and G.E. Sigmon (eds) (2013), Uranium: from cradle to grave, Mineralogical Association of Canada Short Courses 43: $15-119$

43. Plášil J (2014) Oxidation-hydration weathering of uraninite: the current state-of-knowledge. J. Geosci. 59:99-114. https://doi. org/10.3190/jgeosci.163

44. Plášil J (2018) Uranyl-oxide hydroxy-hydrate minerals: their structural complexity and evolution trends. Eur J Mineral 30:237-251. https://doi.org/10.1127/ejm/2017/0029-2690

45. Christ C, Clark J (1960) Crystal chemical studies of uranyl oxide hydrates. Am Mineral 45:1026-1061

46. O'Hare P, Lewis B, Nguyen S (1988) Thermochemistry of uranium compounds XVII. Standard molar enthalpy of formation at $19815 \mathrm{~K}$ of dehydrated schoepite UO3.0.9H2O. Thermodynamics of (schoepite + dehydrated schoepite + water). J Chem Thermodyn 198820:1287-1296. https://doi.org/10.1016/00219614(88)90165-6

47. Hyatt NC, Corkhill CL, Stennett MC, Hand RJ, Gardner LJ, Thorpe CL (2020) The hades facility for high activity decommissioning engineering and science: part of the UK national nuclear user facility. IOP Conf Ser Mater Sci Eng 818:012022. https://doi. org/10.1088/1757-899X/818/1/012022

Publisher's Note Springer Nature remains neutral with regard to jurisdictional claims in published maps and institutional affiliations. 